\title{
Aspekter ved indførelsen af webbaseret læring i tandlægers efteruddannelse
}

\author{
Hvornår og hvordan er webbaseret læring (WBL) relevant?
}

\section{Per Deleuran}

Uddannelseskonsulent, tandlæge

Odontologisk Institut

Københavns Universitet

pde@odont.ku.dk

http://www.odont.ku.dk

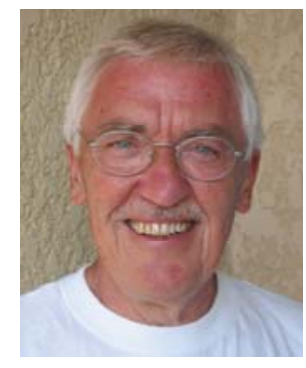

Per Deleuran er uddannet tandlcege i 1962. Har siden vcret ansat som underviser ved Tandlcegeskolen $i$ København i 11 år efterfulgt af 29 år som uddannelsessekretcer og -chef $i$ Dansk Tandlcegeforening. Har de sidste fire år vœret ansat ved Tandlæegeskolen i København med henblik på at udvikle en systematisk og delvis webbaseret efteruddannelse for færdiguddannede tandlæger. Forfatteren har sideløbende med ovennæevnte ansættelser haft privat deltidspraksis i København.

Der hersker enighed om, at implementering af webbaseret læring (WBL) som dele af en efteruddannelse vil kunne medføre store økonomiske og pædagogiske fordele. Indarbejdning af WBL er fortsat en økonomisk resursekrævende opgave. Med de rette økonomiske midler vil tilpasning af eksisterende modeller til en dansk odontologisk efteruddannelse dog kunne ske inden for overskuelig tid og udgift. En investering i WBL er derfor en engangsinvestering som på sigt vil kunne betales tilbage ved menneskelige og fysiske resursebesparelser. I WBL vil begrebet Den interaktive evaluering ifølge nyere undersøgelser være et lovende pædagogisk værktøj. Metoden rummer store fordele ved bl.a. at sikre den enkelte deltagers evne til selvevaluering og styring af egen indlæring.

I efteråret 2005 startede TKU Efteruddannelsen (Tandlægeskolen Københavns Universitet) en systematisk efteruddannelse i fagområderne Oral kirurgi, Parodontologi og Ledelse. TKU tilbyder en ny type efteruddannelse, som på en systematisk og kvalificeret måde og ved delvis brug af WBL gennemgår de enkelte fagområder og opjusterer den enkelte deltagers viden.

\section{Tidligere pædagogisk praksis}

Nogen egentlig overordnet metodik for pædagogisk praksis kan næppe siges at have eksisteret i mange års odontologisk efteruddannelse. Traditionelt har praksis i undervisningssituationen været overladt til den enkelte underviser.

Undervisningspraksis har hovedsageligt delt sig mellem formerne: forelæsning, gruppeundervisning og øvelser/opgaver. Andre tiltag har været symposier, seminarer og projektarbejder, men en del af disse undervisningsformer har ikke kunnet bygges op om elevcentreret pædagogik, og projektarbejderne har altid udgjort en væsentlig mindre del af den samlede efteruddannelse. 
En gængs opfattelse udefra har da også været, at undervisere leverer viden og automatisk overfører den til tandlægerne. Undervisningen har derfor i høj grad haft en meddelende karakter snarere end en igangsættende proces.

Flere uformelle samtaler med undervisere fra universitetsmiljøet afslører at de studerende forventer at få en verden serveret. Når dette er sagt, har der også hos tandlægerne været den samme forventning, og mange har følt det irriterende når for meget bliver overladt til den enkeltes eget ansvar. Samtidig må man konstatere at tandlægerne i de seneste år har søgt de korte resultatorienterede kurser og fravalgt den dybdegående akademiske efteruddannelse.

Et af de kritikpunkter, der er rejst fra tandlægernes side, er en bekymring i forholdet til om WBL vil forringe kontakten mellem underviser og tandlæge. Man opfatter den personlige kontakt med underviseren som meget væsentlig. Den nævnte bekymring synes ikke at være relevant, da erfaringer med fjernundervisning viser at den lærende faktisk oplever en tættere personlig kontakt til underviseren.

WBL må ikke betyde afskaffelse af tilstedeværelsesundervisningen begrundet i vigtigheden af den personlige kontakt. Dette kan godt virke paradoksalt set i lyset af at den reelle personlige kontakt ikke synes at have været overvældende i tidligere og gældende praksis. Hvis denne form for undervisning skal afskaffes, skal det ske af andre årsager, som skal omtales senere.

Efterfølgende gennemgås de argumenter der kan være for at anvende WBL i efteruddannelsen af tandlæger på Københavns Universitet (KU) nu og i fremtiden, og hvilke pædagogiske overvejelser der skal gøres i forbindelse med implementering af WBL som et element i undervisningen.

\section{Hvorfor WBL i tandlægernes efteruddannelse?}

Et helt overordnet argument for at indføre WBL er, at vi står over for en ændring af tandlægers forudsætninger og forventninger til den efteruddannelse der udbydes. Det skyldes at folkeskolen og gymnasiet ved deres undervisning i højere grad tager højde for den individuelle dimension i læringsprocessen og samtidig lægger vægt på at basere læringsprocesser på projektarbejdsformen. Udviklingen der går i retning af at ophæve klassestrukturer, vil forstærke den holdningsændring hvor tandlægerne i deres egenskab af kursusdeltagere i fremtiden vil møde med en forventning om differentieret undervisning frem for holdundervisning. Ovenstående skyldes bl.a. at yngre tandlæger er power users of technology, da de er opvokset og har fungeret med de tilbud den teknologiske udvikling har tilbudt gennem de to sidste årtier. Dette har på ganske fundamental vis ændret den måde hvorpå man lever, lærer og arbejder. Fremtidens tandlæger vil derfor komme med en viden, social norm og et værdisæt, der kun er fælles med deres jævnaldrende. Det fælles grundlag vil ligge i kendskabet til arbejdsmetoder de er bekendt med fra folkeskole, gymnasium og prægraduat studium. Der vil derfor være behov for at skabe og definere rammer hvor efteruddannelse kan tilbydes alle tandlæger, yngre som ældre, under hensyn til deres individuelle tilgang til læringssituationen.

WBL kan gøre det muligt at formidle indholdet i de odontologiske fag på en måde hvor den enkelte tandlæge kan lære i det tempo som passer ham/hende og med udgangspunkt i hans/hendes faglige niveau, hvorved der opnås en differentieret undervisningsform.

For nogle tandlæger vil ovenstående ikke være argument nok for, at udviklingen inden for efteruddannelse går i denne retning, eller at de yngre tandlæger vil være anderledes end tidligere. Det er derfor vigtigt at se på om der ud over argumentet om udviklingen findes en fornuftig pædagogisk begrundelse for indførelsen af WBL. En pædagogik, der tager udgangspunkt i de nuværende tandlægers forhold, vil kunne begrunde hvorfor vi skal gå i gang nu, og hvorfor WBL er så egnet til de nuværende uddannelseselementer i efter- og videre- 
uddannelsen, hvor mange ikke-yngre tandlæger fortsat repræsenterer generationen før power users of technology.

I det følgende gives nogle argumenter for at WBL kan være nyttigt set ud fra de nuværende tandlægers og underviseres perspektiv. Argumenterne er baseret på udarbejdelsen af rapporten Web-Based Learning (WBL) på Københavns Universitet”, samtaler med inden- og udenlandske eksperter, internetkilder og tilgængelig litteratur.

\section{Kontrol af tandlægernes kompetence}

I en del lande, fx England, Belgien, Schweiz og USA, har sundhedsmyndighederne indført krav om dokumenteret efteruddannelse. Kravene er fastsat som et vist antal uddannelsestimer per år, og der gives kun kredit for de på forhånd af myndighederne godkendte kurser. Der er ikke nogen krav om hvilke fagområder tandlægerne skal vælge i deres kompetenceudvikling. I andre lande findes disse krav ikke, og det er helt overladt til den enkelte tandlæge at vedligeholde sine kundskaber og færdigheder. I Norden er obligatorisk efteruddannelse diskuteret i tandlægeorganisationer og på universiteter, men der er foreløbig ikke taget beslutning om at indføre det. Tværtimod har organisationerne ønsket at efteruddannelse fortsat skal ske ad frivillighedens vej, men at der skal animeres til efteruddannelse, og at der skal anbefales et bestemt antal timer per år. For få år tilbage vedtog man således i tandlægeorganisationerne en konsensus om at anbefale 50 timer per år. De samme organisationer og myndigheder har ligeledes stillet sig positive over for frivillige registreringssystemer som kan administreres af den enkelte tandlæge. I dag arbejdes der med dette i Den Norske Tannlegeforening. I Danmark har TKU Efteruddannelsen, Dansk Tandlægeforening, Tandlægernes Nye Landsforening og Århus Tandlægeskole udarbejdet et registreringssystem kaldet KE-kredit. I al fremtidig efteruddannelse vil der på deltagerbeviserne være anført, hvor mange KE-Kredit-timer udannelsen har givet.

At der arbejdes med at indføre sådanne frivillige registreringssystemer skal ses på baggrund af at den fokus der i dag er på Sundhedsvæsenets kvalitetssikring før eller siden vil betyde, at der vil blive stillet krav til alle medicinalpersoner om registreret efteruddannelse. Ved på nuværende tidspunkt at foreslå frivillig registrering signalerer tandlægeforeningerne og tandlægeskolerne at man er på forkant med kravene, og at man er parat til at tage udfordringen op. Indførelsen af WBL mellem modulerne i en systematisk efteruddannelse vil kunne give KE-Kredit, hvilket ikke har været tilfældet før, hvor al form for hjemmearbejde og selvstudium var for egen regning.

\section{Differentieret undervisning og individuel læring for den enkelte tandlæge}

Mange erfaringer fra universiteterne i såvel København som Malmø samt fra udlandet har vist at den lærende kan have et øget udbytte af WBL i forhold til konventionel undervisning. Erfaring fra fjernundervisning under åben uddannelse påpeger, at undervisningen her er mere differentieret end ordinær forelæsning (face to face). Den enkelte lærende har derved større mulighed for at komme til orde og stille spørgsmål, da man ikke er begrænset af tid til rådighed for undervisningen og hensynet til andre lærende. Mange behøver derfor ikke at bruge tid på emner, de allerede har forstået.

I traditionel forelæsning er det underviseren der er aktiv det meste af tiden, og kun et fåtal af de lærende kommer til orde, mens de lærende står for de fleste af indlæggene i en online webbaseret undervisning. Der er tilsyneladende en større andel af de lærende der har mod på at bidrage med indlæg via WBL end ved forelæsninger. Dette betyder at styringen af undervisningen flyttes fra underviseren til deltagerne, og derved er den med til at udvikle de lærendes selvstændighed. Erfaring fra fjernundervisning viser da også at WBL i modsætning til den klassiske forelæsning i høj grad fremmer deltagerstyring. 
En amerikansk undersøgelse dokumenterer at WBL kan udvikle de lærendes sociale adfærd. Erfaringer fra bl.a. Malmø Högskola og enkelte danske gymnasier viser, at der opnås en bredere kontakt mellem underviser og den lærende i situationer, hvor WBL og tilstedeværelsesundervisning kombineres. Samtidig opnår underviseren via WBL et bedre kendskab til standpunktet hos de lærende, som ikke markerer sig så meget i traditionel undervisning. Fordelen ved dette kendskab er ikke så meget spørgsmålet om kontrol, men mere den mulighed det giver underviseren for at indrette undervisningen efter den enkelte lærende. Til det brug er Den interaktive evaluering som beskrevet herunder et væsentligt hjælpemiddel.

\section{Den interaktive evaluering (IE)}

Indlæring opfattes som værende en dialektisk proces. Indlæring - specielt inden for de akademiske sundhedsuddannelser - er ofte blevet betragtet og vurderet som værende en ikke-interaktiv proces, ofte begrænset til en engangskontrol af videnopfattelse og håndværksmæssige færdigheder. Den løbende tilpasning - den livslange uddannelse - til de eksisterende professionelle omgivelser kræver et meget stort spektrum af viden, hvilket kun kan udvikles og tilegnes gennem en dialektisk proces. Den interaktive evaluering (Figur 1.) er en struktureret evaluering af deltageren baseret på forskellige former for dialog, som hjælper til at evaluere deltagerens evner, kompetence og færdigheder samtidig med, at den udvider og supplerer indlæringsprocessen.

\section{Interactive quality development}

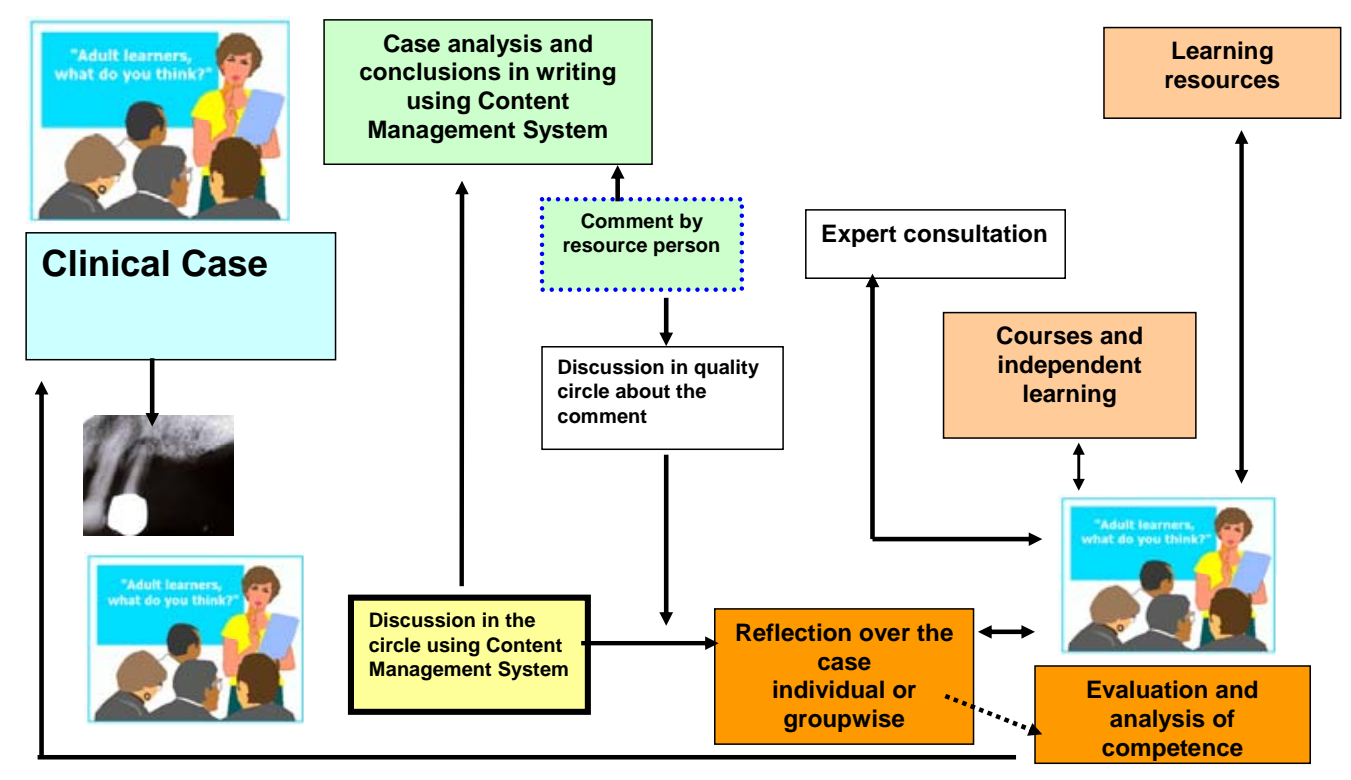

\section{Figur 1. Princippet i Interaktiv evaluering}

IE udnytter deltagerens egen opfattelse og selvevaluering som startpunktet i den dialektiske proces. Via Internettet skal deltageren i første omgang løse nogle opgaver. Opgaverne sammenlignes med lærerens besvarelser, og der gives fortsat via Internettet en fortrolig øjeblikkelig feedback til deltageren. Deltageren skal herefter pga. af lærerens feedback sammenligne sin egen og lærerens besvarelse og ud fra denne sammenligning stille de punkter op, hvor der ikke er overensstemmelse. For hvert punkt, hvor der ikke er overensstemmelse, skal deltageren nu udarbejde en handlingsplan for, hvordan vedkommende vil opdatere sin viden, 
så den i sidste ende kan tåle entydig sammenligning med lærerens. Forskelle, prioriteringer, begrundelser og argumenteringer for netop denne handlingsplan vil blive diskuteret med læreren, som i sin anden feedback skal kommentere deltagerens plan eller give anledning til yderligere overvejelser.

I anden omgang skal deltageren på baggrund af hele undervisningsforløbet evaluere sig selv give sig selv karakter. Karaktererne sammenholdes med de af læreren givne. Denne del af IE er meget væsentlig i den prægraduate undervisning, men kan måske virke for overvældende i postgraduat uddannelse. Det essentielle og mest befordrende i IE er det ovenfor beskrevne pædagogiske forløb, dialogen og den selvevaluering der følger med feedbacken fra læreren.

Modellen for den Interaktive evaluering kan derfor se ud som skematisk vist i Figur 2.

Forbedring,
opfølgning og
evaluering

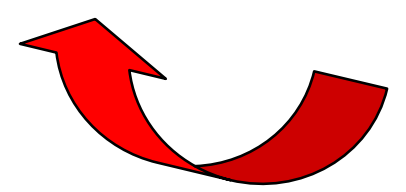

Genspejling, overvejelse og handlingsplan
Anden feedback:

Lærerens kommentar

til handlingsplanen

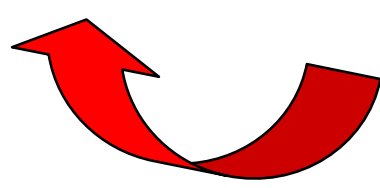

Første feedback:

Sammenligning med

lærerens besvarelse

Deltageropgave

Figur 2. Den interaktive evaluering

\section{Større fleksibilitet for tandlæger i efteruddannelsen}

Mange tandlægers tilværelse er fyldt op af det praktiske og administrative arbejde med at være tandlæge og leder. Dertil kommer et stort pres fra patienter, familie og krav til fritid. Disse helt forståelige forhold må vi som undervisere også forholde os til, for det betyder at tandlægerne ikke har de samme muligheder for at følge den almindelige tilstedeværelsesundervisning som for bare 20 år siden, og det betyder i mange tilfælde at man bortvælger efteruddannelse. Med de muligheder for asynkron undervisning WBL byder på, kan der være en gevinst i form af større fleksibilitet. Tandlægerne er ikke i samme grad bundet til bestemte forelæsninger på bestemte tidspunkter.

På spørgsmålet om hvilke potentialer der ses i WBL, nævner mange tandlæger i de sparsomme undersøgelser der findes i Danmark, selv muligheden for at se/gense et undervisningsprogram og at gennemføre/repetere øvelser etc.

WBL indebærer større mulighed for at sammensætte undervisning på tværs af faggrænser. Flere fremhæver desuden som et potentiale fordelen i, at man kan trække på internationalt anerkendte ressourcer inden for faget (Cochrane, Medline, universitetsservere mv.). 
Kravene til og spørgsmålet om tandlægernes 24 timer i døgnet, hvor den 25. og 26. ikke findes, er fortsat så høje at det kan være svært at se hvorledes man skal øge tilgangen til efteruddannelse. Men en øget fleksibilitet og individualisering af undervisningstilbuddene vil kunne forbedre tandlægernes mulighed for at deltage i efteruddannelse. Med asynkron efteruddannelse (Figur 3) kan tandlægerne få bedre muligheder for at omorganisere deres tid. De vil derfor ikke som før nævnt i samme grad som tidligere være bundet til bestemte forelæsninger og kurser.

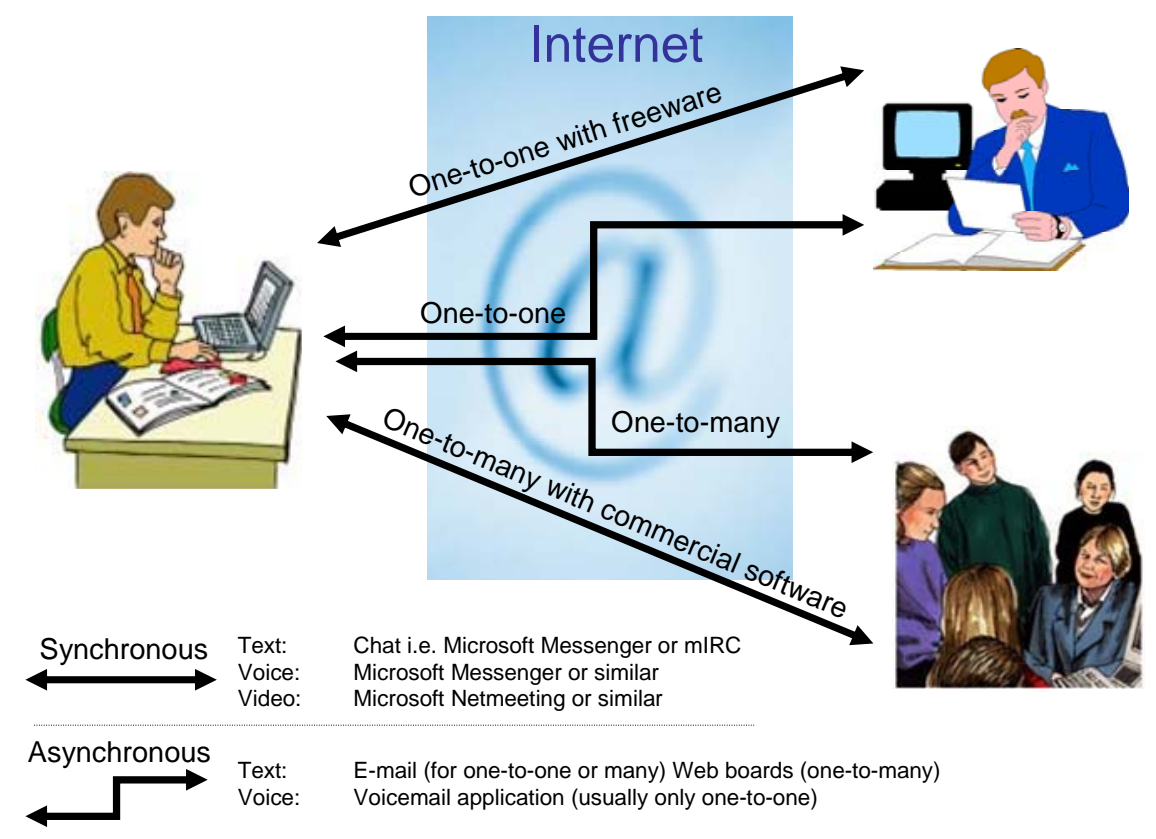

Figur 3. Eksempler på synkron og asynkron efteruddannelse

\section{Synlig struktur og andre rammer for tandlægernes efteruddannelse}

Tandlægerne kan bruge WBL som hjælp til at strukturere tiden mellem forelæsningerne, og der er derfor et potentiale $\mathrm{i}$ at kunne repetere en forelæsning, og navnlig $\mathrm{i}$ at opleve mediet som oplagt til at repetere øvelser. Mulighederne for at kunne trække på andre undervisningsressourcer uden for Danmarks grænser er som tidligere nævnt relevant. Dog vil den faglige kliniske underviser med den konkret praktiske erfaring altid være et must i en efteruddannelse.

WBL med dertil hørende servere (E-læringsplatform) kan give tandlægerne mulighed for at arkivere dokumenter og oprette porteføljer. Navnlig porteføljetanken kan give både tandlægen og underviseren et bedre og mere reflekteret overblik over læringsforløbet. WBL stiller krav til underviserne om at tydeliggøre undervisningens mål, samt til tandlægerne om at sætte ord på deres tanker og være mere konkrete i deres problemformuleringer. Generelt er det væsentligt at holde sig for øje at mange kommunikationssituationer inden for rammerne af WBL kræver en entydig forståelse såvel i synkrone som i asynkrone rum.

\section{WBL kan danne ramme for læring mellem kolleger (kollaborativ læring)}

I perspektivet af en moderne læringsforståelse, baseret på en betragtning om læring som en fælles fleksibel produktion af viden, er kollaborativ læring et interessant aspekt. En af de markante anbefalinger fra pædagogiske eksperter er netop at underviseren skal støtte de lærende i at bruge hinanden mere i læringsprocessen. WBL giver en lang række muligheder for at tilføre kollaborativ læring nye dimensioner i kraft af lærende fællesskaber på tværs af geografiske afstande. 
Kollaborativ læring overflødiggør på ingen måde underviseren, hverken i den fysiske praksis eller i den virtuelle. Tværtimod er underviserens forankring i læringssituationen fortsat en væsentlig pointe uanset læringsforum. Underviseren som coach i de virtuelle diskussioner er derfor et væsentligt aspekt (Figur 4).

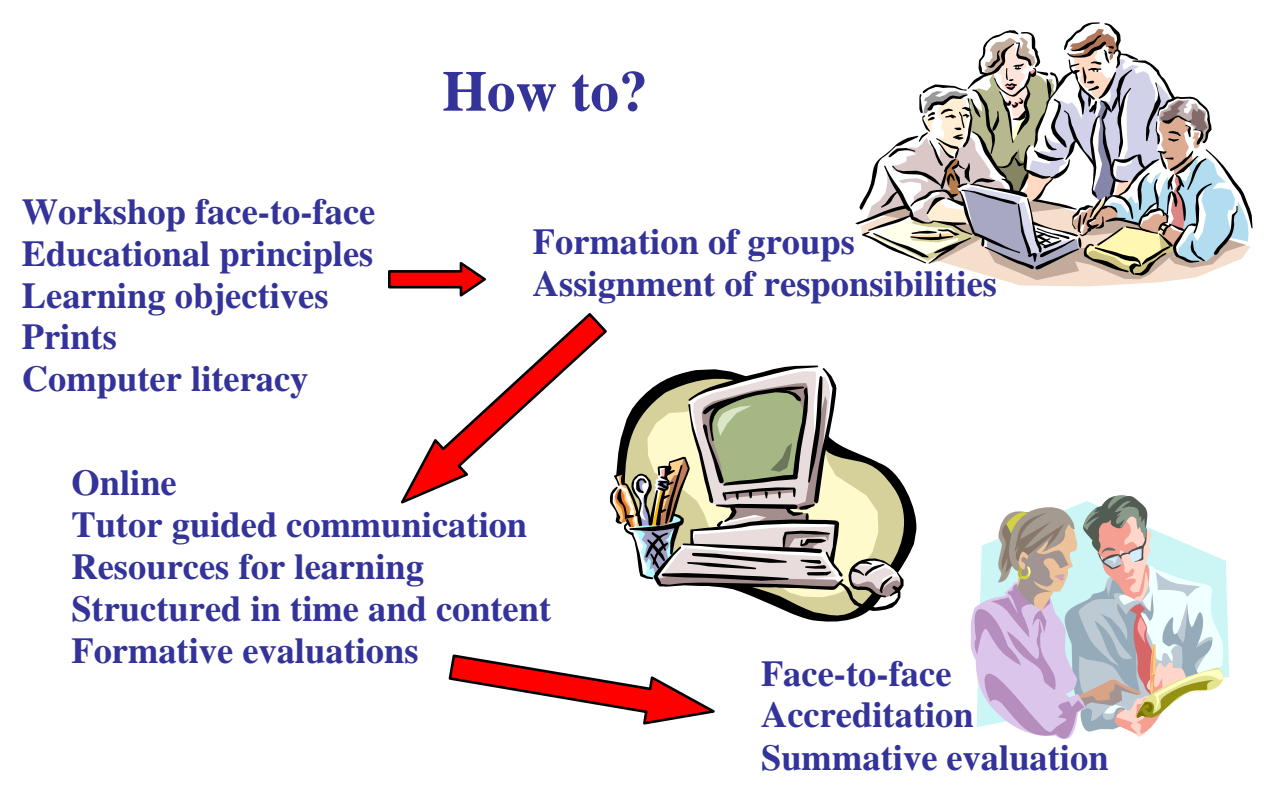

Figur 4. Kollaborativ laring, socialisering og coaching er stcerke elementer i WBL og IE.

\section{Tandlægernes ICT-kompetence udvikles}

Der vil i fremtiden inden for den odontologiske praksis være en forventning eller krav om at tandlæger foruden viden, kunnen og manuelle færdigheder også skal beherske brugen af ICT (Information and Communication Technology) inden for deres erhverv. Det vil derfor i fremtiden være nærliggende, at der indføres læringsmål vedr. ICT-kompetence i tandlægeuddannelsen. Brugen af ICT og e-læringsplatform vil i denne forbindelse give de kommende tandlæger mange af de nødvendige ICT-kompetencer i direkte relation til læringen.

Men også nuværende tandlæger bør lære brugen af ICT, som med stor uundgåelig styrke skyller ind over os i uanede mængder og varianter, om vi så vil det eller ej. En implementering af WBL i tandlægernes løbende efteruddannelse vil være et væsentligt bidrag til at øge denne ICT-kompetence.

\section{Ressourcebesparende}

Nogle af de traditionelle undervisningsformer kræver vanskeligt tilgængelige eller kostbare materialer. Andre forudsætter et stort lokaleforbrug og tekniske hjælpemidler. WBL kan i visse situationer erstatte og reducere disse ressourcekrav, uden at kvaliteten af undervisningen mindskes.

Erfaringer viser dog også at den tid underviserne bruger på undervisningen ikke bliver mindre, ofte tværtimod. Derfor er WBL ikke altid løsningen på efteruddannelsens konstante dilemma i forhold til tid og ressourcer. Omvendt oplever man store fordele med den tidsuafhængighed som man kan opnå ved WBL.

I spørgsmålet om tidsforbruget er det dog væsentligt at man som underviser beslutter sig for, hvordan man vil bruge sine ressourcer. WBL kan tilrettelægges sådan at underviseren mere 
optræder som coachen og sikkerhedsnettet i de virtuelle diskussioner, snarere end som direkte deltagende diskussionsmedlem.

WBL vurderes fra flere pædagogiske sider som endnu en streng at spille på, men hvorvidt der er et reelt større læringsudbytte ved brug af WBL, ligger der kun få vurderinger af. I svenske undersøgelser tyder det på at WBL i den rette kombination med verbal konfrontationsundervisning giver det bedste læringsudbytte, sammenlignet med hver af de to enkelte løsninger. Fremtidens TKU Efteruddannelse satser i dele af Den Systematiske Efteruddannelse på ovennævnte kombination.

\section{Blackboard Learning System (http://blackboard.adm.ku.dk)}

Al undervisning og hjemmearbejde mellem modulerne i TKU Efteruddannelsens systematiske efteruddannelse foregår for nærværende via Blackboard Learning System (Figur 5) der er en af de e-lærings-portaler som bruges på Københavns Universitet, og hvor alle former for meddelelser og materialer kan lægges ud til deltagerne. For at få adgang til portalen får hver deltager tildelt sit eget personlige login og password hvilket forudsætter at hver deltager har en e-mail-adresse, det kan være klinikkens eller en privat, som kan være fundamentet for kommunikation. Al kommunikation mellem modulerne til og fra TKU Efteruddannelsens administration, underviserne og deltagerne vil foregå via Blackboard som er forsynet med et e-mail-system som ligner Microsoft Outlook eller Outlook Express. Denne moderne form for uddannelse og selvlæring har nu været gennemprøvet på de i indledningen nævnte uddannelsesforløb i henholdsvis Oral Kirurgi, Parodontologi og Ledelse, til stor tilfredshed og glæde for deltagerne.

Eksempler på materialer, som er lagt ud:

a) Modulbeskrivelse

b) Timeplan

c) Undervisernes præsentationer (PowerPoint), synopser og vejledninger

d) Undervisernes test og opgaver til deltagerne, udsendt før og mellem modulerne

e) Litteraturreferencer med links til biblioteker, så artiklerne kan læses umiddelbart

f) Links til videoklip med behandlinger og operationer (streaming)

g) Instrumentlister

h) Evalueringer

i) Navne og adresser på undervisere og deltagere

Deltagerne vil automatisk blive udstyret med de værkstøjer (softwares), der skal bruges til at læse PowerPoints, PDF-filer m.v. Ligeledes vil deltagerne kunne downloade en fyldig vejledning i, hvorledes man bruger Blackboard. Der kræves således ikke nogen større ekspertise i edb- og internet-håndtering, man skal blot kunne skrive i Microsoft Word og sende e-mails. Desuden findes der en online assistance styret af TKU Efteruddannelsen, så ingen behøver at være nervøse for ikke at kunne være med. 


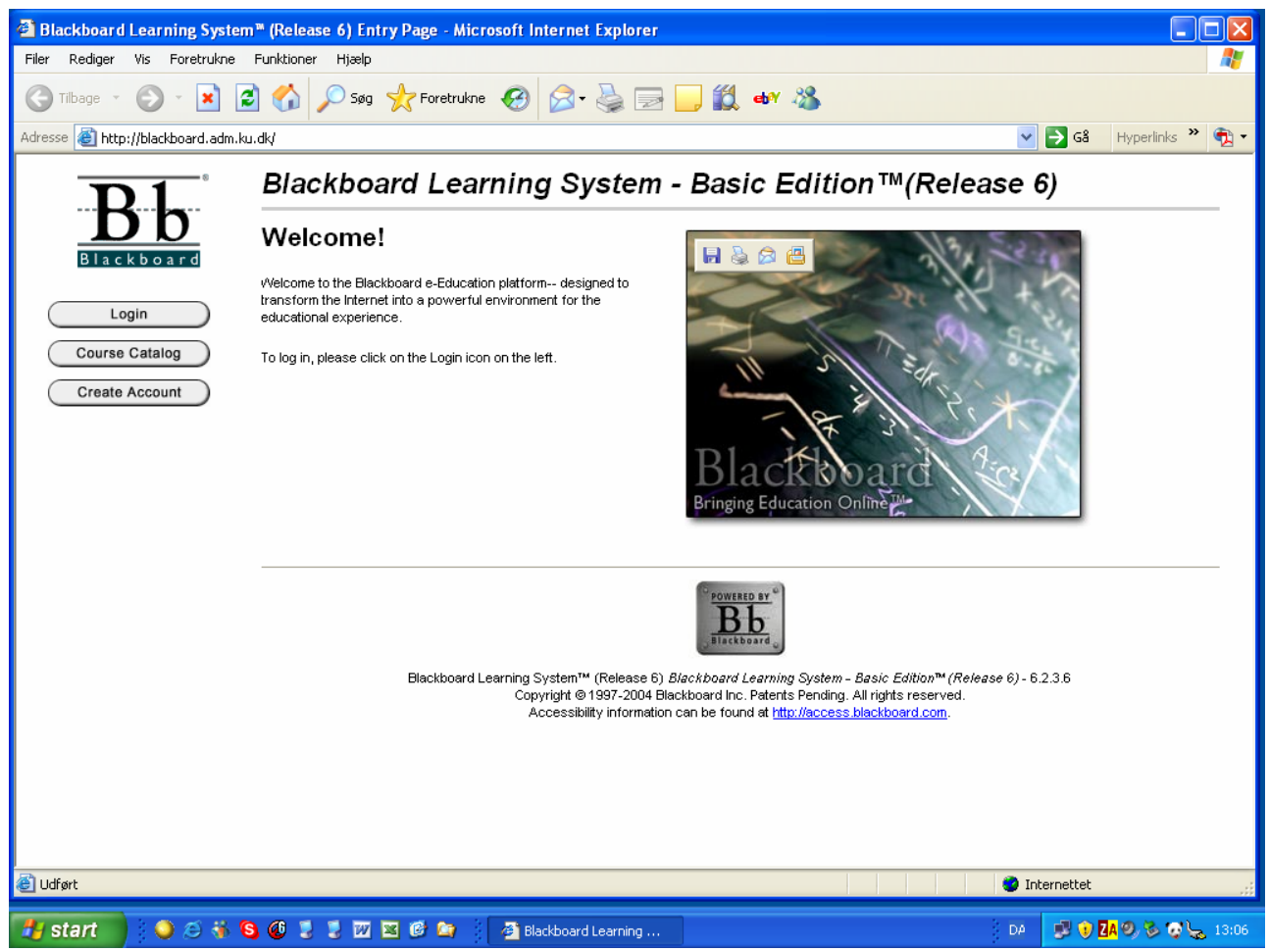

Figur 5. Blackboard Learning System

\section{Konklusion}

Det har i forbindelse med TKU Efteruddannelsens modulopbyggede systematiske efteruddannelse været muligt at indføre intermediær webbaseret efteruddannelse og klare delmål for de enkelte moduler, og på denne måde beskrive for tandlægerne hvad de skal lære. Dette kan udvides til at tandlægerne evalueres på hvilke mål de når, frem for hvilke efteruddannelseskurser de har deltaget i. Dette stiller krav om nogle klare rammer for efteruddannelsen og dermed en større gennemsigtighed for den enkelte tandlæge. Dette kan give en frihed mht. planlægning og gøre det enklere at sammensætte sin efteruddannelse.

Der vil også være mulighed for at der under uddannelsen udarbejdes opgaver der gemmes i en portefølje. Alle disse tiltag vil være med til at udvikle den måde man forøger sin kompetence på i odontologisk erhvervssammenhæng, og også være med til at fremme muligheden for at tandlægen opfatter disse nye tiltag som starten på eller en del af en allerede eksisterende livslang læring. Men man skal være klar over at WBL er mere end en optimering af kendte pædagogiske metoder. De vanskeligheder der kan ligge i vidtgånde asynkron dialog og gruppesamtale, samt den begrænsning der kan ligge i kommunikation uden mulighed for at iagttage kropssprog og andre signaler der fungerer i fysiske undervisningssituationer, må ikke undervurderes.

Det er vigtigt at kombinationen af tilstedeværelsesundervisning (face to face) og webbaseret efteruddannelse foregår i en korrekt afbalancering.

Tandlægeskolen, Københavns Universitet, har i de sidste par år beskæftiget sig med analyser af hvorledes man implementerer WBL i efteruddannelse og er nået til den erkendelse, at tiden er moden til det. Tandlægeskolen opfatter det som en spændende og udviklende opgave at tilbyde WBL til danske tandlæger - og det være sagt ikke uden en vis ydmyghed, fordi så mange faktorer mellem institution, undervisere og tandlæger skal gå op i en højere enhed.

Det er derfor glædeligt, at Københavns Universitet har oprettet Center for webbaseret læring (CWBL) og den tilhørende e-læringsplatform, som hedder Blackboard. Fra efteråret 2005 har 
danske tandlæger været informeret om netop denne platform, og hvorledes de kan bruge den i deres efteruddannelse. Interessen hos de deltagere, som for nærværende gennemgår en systematisk efteruddannelse har været stor, og mange har personligt reageret positivt på denne nyskabelse i efteruddannelsen af dem.

\section{Litteratur}

Mattheos, Nickolas \& Rolf Attstrom, 2003. Learning through examination dialogues: The interactive examination. In: The learning by Dialogues Conference, Malmö 10-11 December 2003.

Mattheos, Nickolas, 2004. Information Technology and Interaction in Learning. Studies of applications in Academic Oral Health Education. Thesis. Centre for Educational Research and Technology in Oral Health and Department of Periodontology, Faculty of Odontology, Malmö University

Janda, Martin S., 2005. Studies on the design of free text communication and video components in Computer Assisted Learning. Thesis. Centre for Educational Research and Technology in Oral Health and Department of Periodontology, Centre for Oral Health Sciences, Malmö University

Establishment of Web-based Learning at the University of Copenhagen. Report by the WBL task force. University of Copenhagen, 2004.

Deleuran, Per, 2003. Indstilling om udvikling af efteruddannelse på Tandlcegeskolen. Københavns Universitet, marts 2003.

Deleuran, Per, 2004. Om implementering af ICT i en Systematisk Efteruddannelse. I: Tandlæagebladet 2004. 592-596.

Deleuran, Per, 2005. Aspekter ved indførelsen af web-baseret læring i tandlægers efteruddannelse. I: Tandlegebladet 2005. 724-727.

Deleuran, Per, 2005. TKU Efteruddannelsen og E-læring. I: Tandlæegebladet 2005. 1066-1071. 